\title{
STUDY OF NORTHERN EVIA'S ULTRAMAFIC ROCKS AS SKID-RESISTANT AGGREGATES IN PAVEMENT CONSTRUCTION
}

\author{
Kosiari S. ${ }^{1}$ \\ ${ }^{1}$ Agricultural University of Athens Postgraduate student, Department of Science, Division of \\ Geological Science and Atmospheric Environment, Laboratory of Mineralogy and Geology, \\ ggeo4kos@aua.gr
}

\begin{abstract}
The study presented in this paper addresses the low skid-resistance factors measure $d$ throughout the Hellenic road network. These low factors are mainly traced to the use of limestone as aggregate resource. The study is mainly focused on the capabili ty of peridotite of Papades region (N.Evia), to be used as aggregate resource since this rock is harder and thus more skid-resistant. Mechanical, petrographical and $m$ ineralogical tests have been conducted in order to determine its suitability for skidresistant aggregates in pavement construction, according to Greek and Internation al standards and specifications.
\end{abstract}

Key words: peridotite, AAV, PSV, AASHTO T 96.

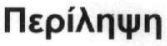

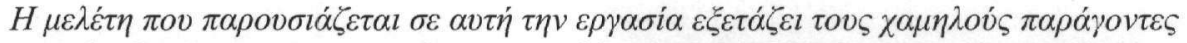

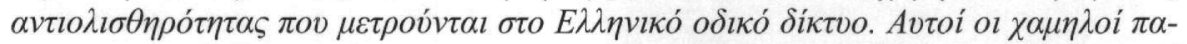

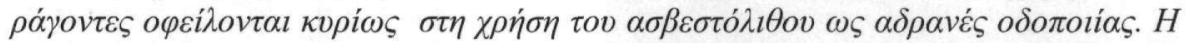

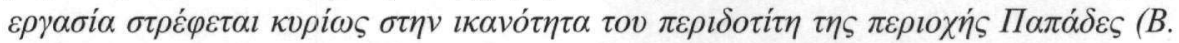

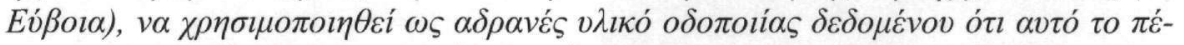

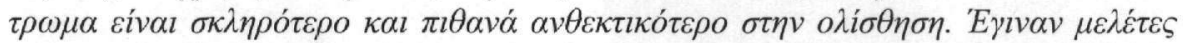

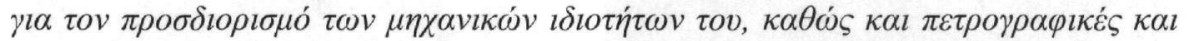

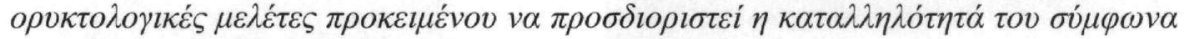

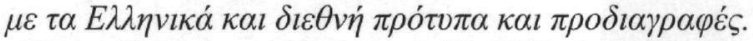

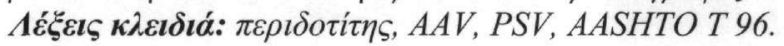

\section{Introduction}

The road and transportation network constitutes even in our days one of the basic development and growth factors of each country. This states the need of extensive study and investigation of all parameters related to the transportation network of a region.

The situation in which the pavings lie (flexible or non-flexible) directly influences the functionality of roads, the duration of transport networks, as well as the safety of transportation. Skid resistance of pavements forms one of the most important factors characterizing their condition. 
Specifically in the Greek regime, the slipperiness problem of pavements is particularly intense, as is proved by the increased number of traffic accidents and the low factors of friction measured at the road network. Main cause of these low factors are attributed to the extensive use of limestone origin aggregates in the asphaltic surfaces, which are materials that are easily smoothened in high degree, as well as to the use of manufacture methods that lead to the asphalt perspiration of the road surfaces. Given that aggregates participate in the composition of asphaltic carpets in percentage higher than $92 \%$, results to the problem being shifted mainly to locating and identifying suitable rocks for aggregate production.

The purpose of this study is the evaluation of the petrographic and mechanical characteristics of peridotites of Papades area (N. Evia), for their ability to be used as skid resistant aggregates for road constructions.

\section{Geological setting}

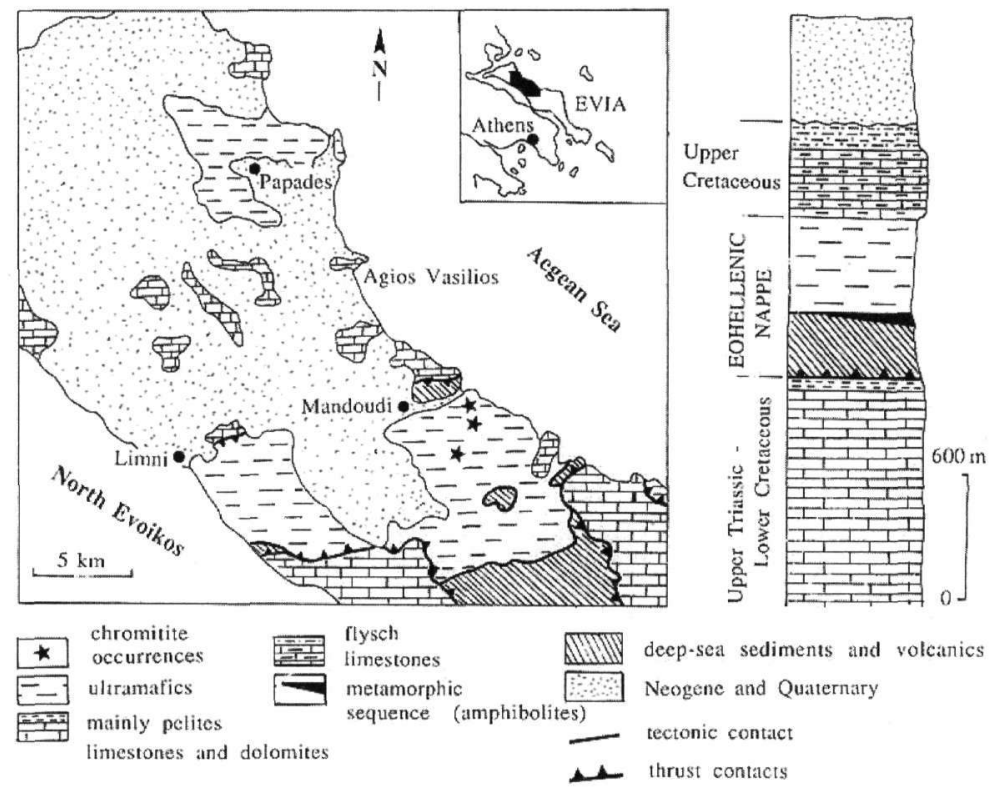

Figure 1 - Sampling region (Papades) and ultramafic rocks appearances in Northern Evia

The geological formations that define the study region are included in the Pelagonian geotectonic zone.

Northern Evia presents an intense surface relief with regular faults, resulting from the extensional tectonics prevailing the last 13 millions years.

The ultramafic rocks of $\mathrm{N}$. Evia are members of the western ophiolithic zone of the Hellenic region. They occupy an area of approximately 150 square kilometres and are known for the large amounts of magnesite deposits that they contain.

Central and northern Evia is composed, with the exception of its Paleozoic crystalline basement, of nonmetamorphic formations, which are distinguished as:

a) Paleozoic crystalline basement, mainly gneiss.

b) Neopaleozoic formations, mainly sandstones and phyllites.

c) Lower - Mid Triassic formations, clastic and mafic igneous rocks.

d) Mid Triassic - Upper Jurassic limestones and dolomites. 
e) Pre-upper Cretaceous tectonic nappe (Heoellenic) which is generally divided in a lower part of volcanosedimentary formations and an upper part, thrusted on the lower part, consisting of ophiolithic formations.

f) Mid - Upper Cretaceous transgressive limestones and flysch sediments.

The Evia regions containing the most important masses of ultramafic rocks are the following: 1) Paramerites, 2) Artaki-Afrati, 3) Psachna, 4) Politika, 5) Limni-Troupi, 6) Prokopi-Pili 7) Papades.

\subsection{Field Study}

Peridotite samples derive from reconnaissance sampling from the Papades region, Northern Evia, along the road Papades - Vasilika, where peridotites (harzburgites) appear to be well-preserved and in full growth.

Papades: In this area, large outcrops of Upper - Jurassic volcanosedimentary formations occur. Ultramafic masses of serpentinized harzburgites with big bastites are overlaid tectonically on these formations. In the region eastern of Achladi, ultrabasic are overlaid tectonically on clastic formations which constitute the stratigraphic evolution of Jurassic limestones.

In the Easternmost region of the ultramafic masses there is a predominance of harzburgites, of various degrees of serpentinizasion, which enclose bodies of dunite. In the western region ultrabasic are fully serpentinized, containing lots and large bastites implying parent rock of harzburgitic origin.

North of Papades region, along the road to Vasilika exist large outcrops of relatively well preserved harzburgite which after microscopic examination present the formal characteristics of tectonite, containing large porphyroclasts of orthopyroxene and long crystals of olivine that present undulose extinction.

\subsection{Petrography}

Harzburgites contain 11-15\% orthopyroxene, 0,2-1\% $\mathrm{Cr}$ - spinel and 0,3-1,5\% clinopyroxene, the rest being mainly olivine.

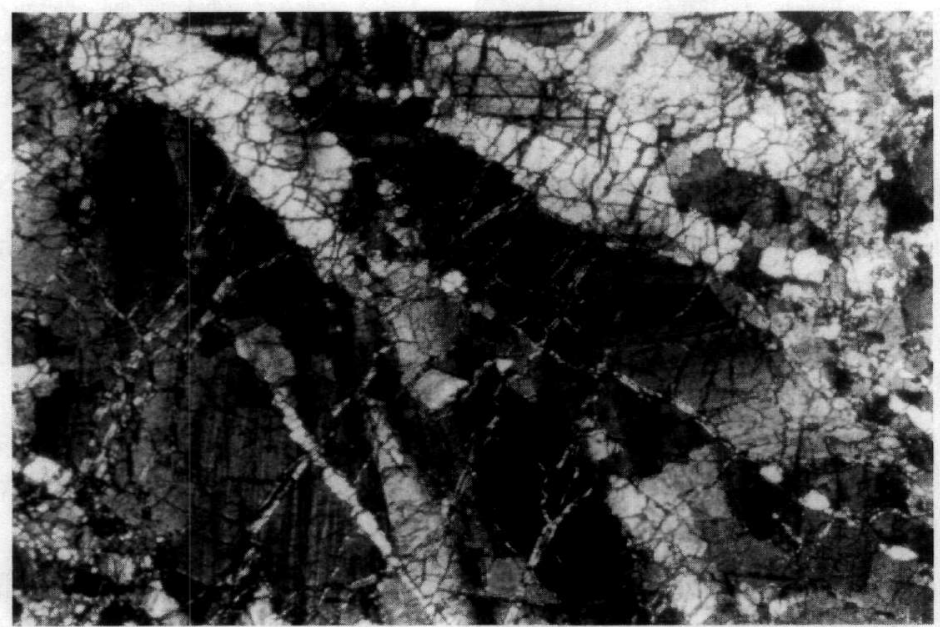

Figure 2 - Microscopic image of tectonized harzburgite taken from the appearances northern of village Papades. Elongated olivine crystals are distinguished presenting undulose extinction (crossed Nichols)

In these rocks we distinguished two types of texture, protogranular and porphyroclastic.

From the examination of thin sections of samples resulted the following: 
Papades 1: In the microphotograph of Figure 2 is shown tectonized harzburgite with elongated olivine crystals, collected from the outcrop northern of the village of Papades, along the road to Vasilika. In certain crystals the length to width ratio exceeds the value of 10 . Also the olivine crystals show undulose extinction. Crystals of orthopyroxene present grey colour and thin veins are serpentine (crossed Nichols).

Papades 2: Microscopic photograph of grainy harzburgite from the Vasilika region. At the centre of the photograph, tremolite crystals are distinguished (crossed Nichols).

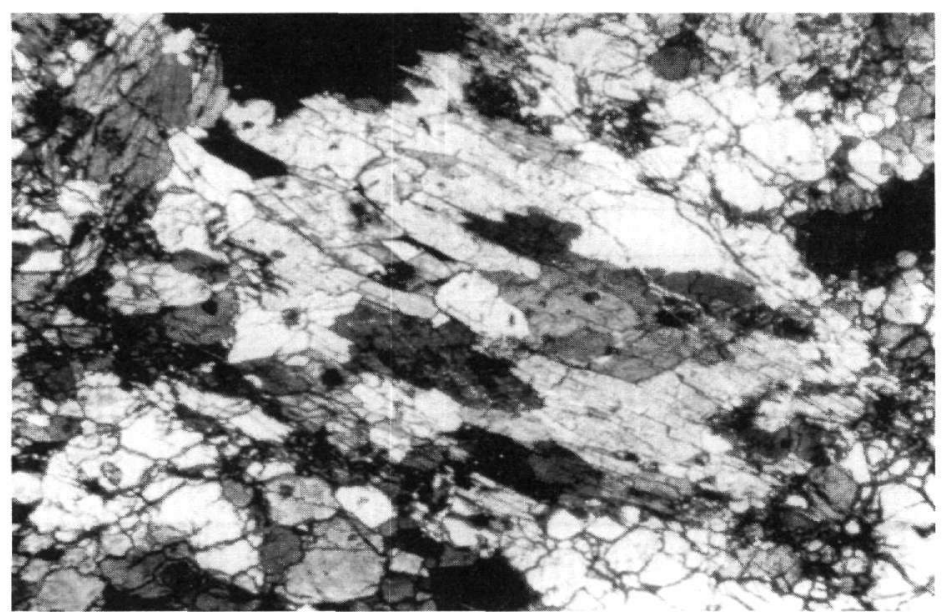

Figure 3 - Microscopic image of granulated harzburgite with tremolite (crossed Nichols)

\subsection{Mineral Chemistry}

The most important minerals (olivine, ortho - and klino - pyroxene, amphibole, serpentine and chromite) of the collected samples were analyzed by microprobe.

Table 1 - Microprobe analysis of olivine from the ultramafics of N. Evia

\begin{tabular}{|l|r|r|r|r|}
\hline $\begin{array}{l}\text { Analysis } \\
\mathbf{N r}\end{array}$ & $\mathbf{1}$ & $\mathbf{2}$ & $\mathbf{3}$ & $\mathbf{4}$ \\
\hline $\mathrm{Wt} \%$ & & & & \\
\hline $\mathrm{Al}_{2} \mathrm{O}_{3}$ & 0 & 0 & 0 & 0 \\
\hline $\mathrm{TiO}_{2}$ & 0 & 0 & 0 & 0 \\
\hline $\mathrm{SiO}_{2}$ & 41,26 & 41,45 & 42 & 41,65 \\
\hline $\mathrm{MgO}$ & 51 & 49,6 & 49,4 & 49,75 \\
\hline $\mathrm{CaO}$ & 0 & 0 & 0,1 & 0 \\
\hline $\mathrm{MnO}$ & 0,01 & 0 & 0 & 0 \\
\hline $\mathrm{FeO} *$ & 7,3 & 8,55 & 8,6 & 8,7 \\
\hline $\mathrm{Na}{ }_{2} \mathrm{O}$ & 0 & 0,02 & 0,02 & 0,03 \\
\hline $\mathrm{K}_{2} \mathrm{O}$ & 0 & 0,03 & 0,01 & 0,01 \\
\hline $\mathrm{Cr} \mathrm{O}_{3}$ & 0 & 0,16 & 0 & 0 \\
\hline $\mathrm{NiO}$ & 0,37 & 0,37 & 0,38 & 0,4 \\
\hline $\mathrm{TOTAL}$ & 99,94 & 100,18 & 100,51 & 100,54 \\
\hline * Total iron as $\mathrm{FeO}$ & & & \\
\hline
\end{tabular}


Table 2 - Microprobe analysis of orthopyroxene from the ultramafics of N. Evia

\begin{tabular}{|l|r|r|r|r|}
\hline $\begin{array}{l}\text { Analysis } \\
\mathbf{N r}\end{array}$ & $\mathbf{1}$ & $\mathbf{2}$ & $\mathbf{3}$ & $\mathbf{4}$ \\
\hline $\mathrm{Wt} \%$ & & & & \\
\hline $\mathrm{Al}_{2} \mathrm{O}_{3}$ & 0,85 & 0 & 0 & 0 \\
\hline $\mathrm{TiO}_{2}$ & 0 & 0 & 0 & 0 \\
\hline $\mathrm{SiO}_{2}$ & 57,15 & 57,85 & 58,05 & 57,8 \\
\hline $\mathrm{MgO}$ & 34,6 & 35,3 & 34,6 & 35,2 \\
\hline $\mathrm{CaO}$ & 1,3 & 0,45 & 0,5 & 0,5 \\
\hline $\mathrm{MnO}$ & 0 & 0 & 0 & 0 \\
\hline $\mathrm{FeO} *$ & 4,8 & 5 & 5,9 & 5,9 \\
\hline $\mathrm{Cr} \mathrm{O}_{3}$ & 0,5 & 0,4 & 0,4 & 0,35 \\
\hline $\mathrm{NiO}$ & 0 & 0 & 0,11 & 0,1 \\
\hline $\mathrm{TOTAL}$ & 99,2 & 99 & 99,56 & 99,85 \\
\hline \multicolumn{2}{|l|}{ * Total iron as $\mathrm{FeO}$} & & & \\
\hline
\end{tabular}

Table 3 - Microprobe analysis of clinopyroxene from the ultramafics of N. Evia

\begin{tabular}{|l|r|r|r|r|}
\hline \begin{tabular}{l|r|r|} 
Analysis \\
$\mathbf{N r}$
\end{tabular} & $\mathbf{1}$ & $\mathbf{2}$ & $\mathbf{3}$ & $\mathbf{4}$ \\
\hline $\mathrm{Wt} \%$ & & & & \\
\hline $\mathrm{Al}_{2} \mathrm{O}_{3}$ & 1 & 0,6 & 0,8 & 0,55 \\
\hline $\mathrm{TiO}_{2}$ & 0 & 0,01 & 0,03 & 0 \\
\hline $\mathrm{SiO}_{2}$ & 54,2 & 55,1 & 54,2 & 55,1 \\
\hline $\mathrm{MgO}$ & 18,2 & 18 & 18,7 & 18,1 \\
\hline $\mathrm{CaO}$ & 24,1 & 25 & 24,9 & 24,8 \\
\hline $\mathrm{MnO}$ & 0 & 0 & 0 & 0 \\
\hline $\mathrm{FeO}$ & 2 & 1,7 & 1,9 & 1,5 \\
\hline $\mathrm{Cr} \mathrm{O}_{3}$ & 0,7 & 0,5 & 0,5 & 0,6 \\
\hline $\mathrm{NiO}$ & 0 & 0 & 0 & 0 \\
\hline $\mathrm{TOTAL}$ & 100,2 & 100,91 & 101,03 & 100,65 \\
\hline \multicolumn{2}{|l|}{$*$ Total iron as $\mathrm{FeO}$} & & & \\
\hline
\end{tabular}

Silicate minerals: The microanalyses showed that olivine is Fo $91-92.5$, orthopyroxene is enstantite $(\mathrm{MgO}=34,60-35,75$ and $\mathrm{FeO}=4,80-5,90$, wt.\%), clinopyroxene is diopside and amphibole is tremolite.

Mineral compositions were analyzed by using an Ames Research Laboratory electron microprobe, Type SEMQ.

The analyses were performed with an acceleration voltage of $15 \mathrm{KV}$, a sample current of $20 \mathrm{nA}$, and a minimum electron beam size, of $0,2 \mu \mathrm{M}$.

Count times were used that yielded a standard deviation of the counting statistics of less than $1 \%$ for minor elements.

The EMMA program written at the Eidgenössische Technische Hochschule Zürich, was used for correction. 
Table 4 - Microprobe analysis of amphibole from the ultramafics of N. Evia

\begin{tabular}{|l|r|r|r|r|}
\hline $\begin{array}{l}\text { Analysis } \\
\mathbf{N r}\end{array}$ & $\mathbf{1}$ & $\mathbf{2}$ & $\mathbf{3}$ & $\mathbf{4}$ \\
\hline $\mathrm{Wt} \%$ & & & & \\
\hline $\mathrm{Al}_{2} \mathrm{O}_{3}$ & 0 & 0,6 & 0,7 & 0 \\
\hline $\mathrm{TiO}_{2}$ & 0 & 0 & 0 & 0 \\
\hline $\mathrm{SiO}_{2}$ & 58 & 56,6 & 55,75 & 57,5 \\
\hline $\mathrm{MgO}$ & 23,6 & 23 & 24 & 23,75 \\
\hline $\mathrm{CaO}$ & 13,15 & 12,5 & 11,7 & 12,95 \\
\hline $\mathrm{MnO}$ & 0 & 0 & 0 & 0 \\
\hline $\mathrm{FeO} *$ & 1,5 & 2,1 & 2,05 & 1,85 \\
\hline $\mathrm{Na}_{2} \mathrm{O}$ & 0 & 0,1 & 0,1 & 0,1 \\
\hline $\mathrm{K}_{2} \mathrm{O}$ & 0 & 0,02 & 0,03 & 0,04 \\
\hline $\mathrm{Cr}_{2} \mathrm{O}_{3}$ & 0,2 & 0,65 & 0,7 & 0,25 \\
\hline $\mathrm{NiO}^{\mathrm{TOTAL} *}$ & 96,45 & 95,67 & 95,13 & 96,54 \\
\hline $\mathrm{TOT}$ & 0 & 0,1 & 0,1 & 0,1 \\
\hline$*$ Total iron as $\mathrm{FeO}$ & & & \\
\hline \multicolumn{2}{|c|}{$* *$ Water free } & & & \\
\hline
\end{tabular}

\section{Aggregates}

As such are known the sieve graded materials (sands, gravels, crushed stones, scoria) of natural or industrial origin, that are used either with adhesive means (concrete, asphalt) or as raw materials (ballast of railway trails, dams, harbour construction) in various technical constructions. Aggregates offer volume and higher resistance in various technical projects. One of their many characteristics is that they do not react chemically with adhesive materials, but present natural cohesion because of the geometry of their grains and their weight.

\subsection{Mechanical Tests - Results}

The mechanical properties that have been measured at the laboratory, according to international and Greek specifications are: a) Standard Method of Test for Resistance to Degradation of SmallSize Coarse Aggregate by Abrasion and Impact in the Los Angeles Machine, b) Method for determination of the polished-stone value (PSV), c) Method for determination of Aggregate Abrasion Value (AAV), d) Determination of Point load index, e) Uniaxial compression deformability test .

Tests a), b) and c) took place at the Central Laboratory of Public Works (KE $\Delta \mathrm{E})$ of the General Secretariat of Public Works ( Hellenic Ministry of Enviroument, Physical Planning and Public Works), while the remaining two took place at the Mineralogy-Geology Laboratory of the Agricultural University of Athens.

\subsection{Standard Method of Test for Resistance to Degradation of Small-Size Coarse Aggregate by Abrasion and Impact in the Los Angeles Machine}

The test is executed, according to American specifications AASHTO, in aggregates of nominal size smaller than $37,5 \mathrm{~mm}$, using the Los Angeles apparatus.

The purpose of this test is to determine the degradation that befalls in graded aggregates under the effect of friction and percussion forces. 
According to Greek specifications, the highest permissible value, for aggregates to be used in bases and subbases of paving layers is considered to be $40 \%$. When aggregates are used for pavements of intense traffic, the highest permissible values are those that are given in Table 5.

The test results for Papades peridotite gave LA: 47,2\%.

\subsection{Method for determination of the polished-stone value (PSV)}

This test determines the behaviour of aggregates to the abrasive action of vehicle tyres. The test constitutes of two parts:

- in the first part the aggregate grains suffer an accelerating polish and

- in the second part the achieved polish amount is measured with the British Pendulum apparatus. The resulting value is called Polished Stone Value (PSV).

The test is executed according to British specifications BS 812 or according to American specifications AASHTO T 279. The laboratory test complied with the British Standards (BS 812)

Table 5 also presents the required PSV values according to the Greek specifications.

The test results for Papades peridotite gave PSV: 45 .

\subsection{Method for determination of Aggregate Abrasion Value (AAV)}

This test determines the behaviour of aggregates to the abbrasion resulting from vehicle tyres.

The AAV along with PSV completely characterize the aggregate hardness and their suitability for use in surface layers of pavements.

Table 5 summarizes the limits proposed by the Greek specifications.

The test is executed according to British specifications BS 812/75.

The test results for Papades peridotite gave AAV: 4,8.

Table 5 - Limit values for Los Angeles, PSV, and AAV tests for hard aggregates of surface layers according to the Greek Technical Specifications

\begin{tabular}{|c|c|c|c|c|}
\hline Traffic & Light & Medium & Heavy & Very Heavy \\
\hline Daily traffic load per lane & Up to 500 & $501-3000$ & $3001-8000$ & $>8000$ \\
\hline Max. Los Angeles Value & $30 \%$ & $28 \%$ & $26 \%$ & $24 \%$ \\
\hline Min. (PSV) & & & & 60 \\
Dangerous Positions, Cat.A & 50 & 55 & 55 & 60 \\
Normal Positions, Cat.B & 45 & 50 & - & - \\
Safe Positions, Cat. & - & 45 & 10 & 8 \\
\hline Max. (AAV) & 14 & 12 & & \\
\hline
\end{tabular}

Table 6 - Results Summary

\begin{tabular}{|l|l|l|l|}
\hline Los Angeles & \multicolumn{2}{|l|}{$47,2 \%$} \\
\hline PSV & 45 \\
\hline AAV & 4,8 \\
\hline Point Load Index (mean) & \multicolumn{2}{|l|}{$\boldsymbol{\sigma}_{\mathrm{c}}: 108,74 \mathrm{MPa}$} & $\mathbf{I}_{\mathbf{S ( 5 0 )}}: 4,9 \mathrm{MPa}$ \\
\hline Sample П11: Elasticity Index(E) & Poisson ratio (v) & $14,184 \mathrm{GPa}$ & 0,187 \\
\hline Sample П12: Elasticity Index(E) & Poisson ratio (v) & $13,082 \mathrm{GPa}$ & 0,327 \\
\hline
\end{tabular}




\section{Conclusions-Discussion}

Aggregates may derive from igneous, sedimentary or metamorphic rocks. Almost every species of rocks have been tested as pavement materials, offering valuable experience about the selection of the most suitable for the asphaltic layer.

As aggregates are considered: sands, gravels, crushed stones, scoria and other similar materials of inorganic constitution, natural or artificial origin, which are used with either adhesive means (cement, asphalt etc.), for the formation of suitable mixtures for various constructions (concretes, asphaltic mixtures, etc.), or even at their initial form.

Test Method For Resistance To Degradation Of Large-Size Coarse Aggregate By Abrasion And Impact In The Los Angeles Machine for our sample, resulted to 47,2 \%. This value is not considered to be satisfactory according to the Greek Technical Specifications (Table 5) since the highest allowed rates of degradation for light, medium, heavy and very heavy traffic are respectively $30 \%, 28 \%, 26 \%$ and $24 \%$.

Determination of the polished-stone value test (PSV) resulted to 45 . This value is considered to be satisfactory according to the Greek Technical Specifications (Table 5), for light traffic and normal positions as well as for medium traffic and safe positions.

Determination of Aggregate Abrasion Value (AAV) resulted to 4,8. This value is considered to be satisfactory after according to the Greek Technical Specifications (Table 5), since the highest values of AAV for light, medium heavy and very heavy traffic are over 4,8.

The Point Load Index test resulted to a mean value of $\sigma_{\mathrm{c}}: 108,74 \mathrm{MPa}$, while the value $\mathrm{I}_{\mathrm{s}(50)}: 4,9$ $\mathrm{MPa}$ indicates that the rock is characterized as a high endurance one and thus could be further examined.

The measurements for the determination of Poisson ratio are: for sample $\Pi 11, \mathrm{n}=0,187$ and for sample $\Pi 12, \mathrm{n}=0,327$ and are considered to be satisfactory, since Poisson ratio must not exceed the value of 0,5 . The Elasticity Index for $\Pi 11$ and $\Pi 12$ respectively are: $E=14,184 \mathrm{GPa}$ and $E=13,082 \mathrm{GPa}$, while the resistance in Uniaxial compression for $\Pi 11$ is $s_{c}=33,73 \mathrm{MPa}$ and for $\Pi 12$ is $\mathrm{s}_{\mathrm{c}}=31,85 \mathrm{MPa}$. Elasticity factors $(\mathrm{E}, \mathrm{n})$ constitute basic parameters of rock resistance. Even if they are not required by specifications for pavement construction, nevertheless they were determined because the rocks used in the road construction suffer high pressures from the charges result thus making E,n, important parameters.

Microscopical observations showed that our samples are constituted of olivine, orthopyroxene and tremolite crystals. Olivine crystals present undulate supression.

Although the laboratory tests indicated that our samples did not match all the requirements for asphaltic layer use (failed Los Angeles test), this does not prevent its use for other road constructions. The study and characterization of similar rocks found in adequate amounts, should continue, in order to discover and exploit their characteristics and ability to be used as skidresistant asphaltic layers.

\section{Acknowledgements}

Special thanks to my professors at the Agricultural University of Athens, whose help and advice was invaluable during this study. Also I would like to thank the staff at the laboratory of Geology and Mineralogy (AUA) and the Central Laboratory of Public Works (KE $\Delta \mathrm{E})$ for their help at the implementation of the various tests and measurements required by the specifications.

\section{References}

Le Pichon, X., and Angelier, J., 1979. The Hellenic arc and trench system, Tectonophysics, 60. 
Serelis, K., et al.. 2004. Study of the wall rock alteration occurring in ultramafic rocks hosting magnesite deposits, Evia, Greece, Bulletin of the Geological Society of Greece, XXXVI.

Katsikatsos, G., 1977. La structure tectonique d'Attique et Eubee, VI Coll. On the Geol. of the Aegean Reg., Athens, I.

Katsikatsos, G., et al.. 1986. Geological structure of internal Hellenides (E. Thessaly, SW Macedonia, Euboea, Attica, Northern Cyclades and Lesvos), I.G.M.E., Geol. and Geoph. Res., Special Issue.

Baumgartner, P., and Bernoulli, D., 1976. Stratigraphy and Radiolarian Fauna in a Late JurassicEarly Cretaceous section near Achladi (Evia, Eastern Greece), Eclogae geol.Helv., 69, 3.

Gartzos, E., 1986. On the genesis of cryptocrystalline magnesite deposits in the ultramafic rocks of northern Evia, Greece, Ph.D. thesis, ETH-Zurich.

Gartzos, E., et al., 1990. Chromites from ultramafic rocks of Northern Evia (Greece) and their geotectonic significance, Schweiz. Mineral. Petrogr. Mitt., 70.

Gartzos, E., et al., 1994. Ultramafic rocks of Evia - Eastern Thessaly and the chromitic concentrations that they host, Bulletin of the Geological Society of Greece, XXX/3.

Tsoutsika, P., et al., 2005. Correlation between petrographical and physicomechanical properties of rocks used as aggregates in road costruction, 2nd Conference of the Committee of Economic Geology, Mineralogy and Geochemistry.

Tsikouras, B., et al., 2005. Investigation for the suitability of basic ophiolithic rocks from the Mikroklissoura Grevena area as anti-skid aggregate material and railroad ballast, 2nd Conference of the Committee of Economic Geology, Mineralogy and Geochemistry.

Koukis, G., 2002. Technical Geology.

AASHTO T 96, Standard Method of Test for Resistance to Degradation of Small-Size Coarse Aggregate by Abrasion and Impact in the Los Angeles Machine.

BS 812: Part 14, 1989, British Standard, Testing aggregates, Part 114. Method for determination of the polished-stone value.

BS 812: Part 13, 1990, British Standard, Testing aggregates, Part 113. Method for determination of aggregate abrasion value (AAV).

Nikolaidis, Ath., 1996. Road Construction-Pavings-Materials-Quality Control. 